\title{
Financing Dutch direct investments to transition economies
}

Citation for published version (APA):

van de Laar, M. M. (2004). Financing Dutch direct investments to transition economies. METEOR, Maastricht University School of Business and Economics. METEOR Research Memorandum No. 029 https://doi.org/10.26481/umamet.2004029

Document status and date:

Published: 01/01/2004

DOI:

10.26481/umamet.2004029

Document Version:

Publisher's PDF, also known as Version of record

\section{Please check the document version of this publication:}

- A submitted manuscript is the version of the article upon submission and before peer-review. There can be important differences between the submitted version and the official published version of record.

People interested in the research are advised to contact the author for the final version of the publication, or visit the DOI to the publisher's website.

- The final author version and the galley proof are versions of the publication after peer review.

- The final published version features the final layout of the paper including the volume, issue and page numbers.

Link to publication

\footnotetext{
General rights rights.

- You may freely distribute the URL identifying the publication in the public portal. please follow below link for the End User Agreement:

www.umlib.nl/taverne-license

Take down policy

If you believe that this document breaches copyright please contact us at:

repository@maastrichtuniversity.nl

providing details and we will investigate your claim.
}

Copyright and moral rights for the publications made accessible in the public portal are retained by the authors and/or other copyright owners and it is a condition of accessing publications that users recognise and abide by the legal requirements associated with these

- Users may download and print one copy of any publication from the public portal for the purpose of private study or research.

- You may not further distribute the material or use it for any profit-making activity or commercial gain

If the publication is distributed under the terms of Article $25 \mathrm{fa}$ of the Dutch Copyright Act, indicated by the "Taverne" license above, 


\title{
Financing Dutch direct investments to transition economies
}

\author{
Mindel van de Laar $^{\mathrm{a}}$
}

July 2004

${ }^{\mathrm{a} D e p a r t m e n t ~ o f ~ E c o n o m i c s, ~ M a a s t r i c h t ~ U n i v e r s i t y, ~ t h e ~ N e t h e r l a n d s ~}$

\section{Summary:}

Firms interested in a direct investment in a transition countries often face difficulties in obtaining external finance. In this study Dutch survey data are used to check if financial obstacles are an important argument for Dutch firms not to engage in an FDI or if other nonfinancial arguments prevail in the decision not to invest. The analysis shows that financial problems are indeed large, but the major arguments for firms not to invest are not financial in nature. The uncertainty of the investment, lack of time and capacity and internal arguments are most often mentioned as obstacles for an FDI.

Keywords: Financing, Foreign Direct Investments, Investment Decision Making, Small and Medium Sized Enterprises

\section{Address:}

Mindel van de Laar

University of Maastricht, Faculty of Economics and Business Administration, Department of Economics, P.O. Box 616, 6200 MD Maastricht, the Netherlands

Telephone: $\quad+31(0) 433882685$

Fax: $\quad+31(0) 433884864$

Email: m.vandelaar@algec.unimaas.nl

\section{Acknowledgement:}

I would like to thank Dr. Jaap Bos, Mrs. Anne Kloosterboer (Ecorys-NEI), Dr. Joan Muysken and the members of the Maastricht Interdepartmental Lecture seminar for their advice. 


\section{Introduction}

The size of Dutch direct investment flows to transition countries is often considered high because relatively many Dutch enterprises invest in the region. On the other hand there is evidence that many more Dutch firms are in principle interested in an investment but never really undertake the action (van de Laar, 2004). Difficulties in financing the investment are often mentioned as an important obstacle, even though the financial sector in the transition countries has improved considerable the last decade (EBRD, 1999; Pissarides, 2001; Klapper et al, 2002). The question this study focuses on is whether financial obstacles are indeed the main reason for firms not to invest in the transition region, or if other less often mentioned factors also play an important role in this decision.

In 1989 the countries in Central and Eastern Europe started a transition to a market economy, followed by the former Soviet Union (FSU) in 1991. While the changes were enormous for the CEECs (Central and Eastern European countries) and Central Asia, also for the Netherlands the collapse of communism was influential (EBRD, 1999). Not only the hostility between the East and West decreased as the cold war ended, but at the same time a huge market opened up for trade and investments. Foreign trade and investments were always kept as low as possible in the 20th century (Ebbersbach, 1982). Given that the focus in the socialist countries was on industrialization, there was a shortage of consumer goods and the quality of the goods that were available was generally low. The transition countries thus formed a large new market for Dutch enterprises to explore; countries in which it was now possible to invest (Blanchard, 1997).

In this study the focus is on Dutch direct investments to Central and Eastern Europe and Central Asia in 1990-2000. Engaging in a foreign direct investment (FDI) in a transition country during the 1990s offered attractive prospects for Dutch enterprises. Allowing foreign enterprises to become active in transition countries meant opening up a land of opportunities in the form of a large region with abundant natural resources relatively close by. In addition, the region was characterized by a lack of production and entrepreneurial skills to develop the market in the short run. Given the fact that local and foreign investments were low, possibilities were present in almost every field to set up a company without facing much competition ${ }^{1}$. In other words, if a company delivered a product or service that was absent or of a better quality than the supply in a transition country, or if a company was better able to manage its company efficiently, there were ample possibilities to become profitable. An increase of Dutch FDI in the region in the 1990s was therefore expected and those investments were also expected to be successful ${ }^{2}$ (Meyer, 2000, Lankes et al, 1996).

In 1989 the total stock of Dutch direct investments in the world was 73443 million euro, equaling 0.03 percent of the Dutch GDP. 48 percent of this amount was invested in Europe, 45 percent in North and South America and eight percent in the rest of the world. Dutch FDI to Europe flows mainly to the countries from the European Union ${ }^{3}$. In 1989 less than one percent of this stock was invested in the CEECs or Soviet Union. None of the countries in the CEE region or the former Soviet Union recorded a stock of Dutch FDI above one million euro. The EU countries received an FDI per capita of 88,4 euro

\footnotetext{
${ }^{1}$ Foreign direct investments were kept as low as possible before 1989 in centrally planned economies, but there was some FDI. The presence of foreign companies was allowed for companies that had entered the region before the countries became centrally planned, or in Romania and Hungary after 1971 and 1972 respectively, where joint venture laws were in place (Ebbersbach, 1982).

${ }^{2}$ Foreign direct investment is defined as net inflows (or stock) of investment to acquire a lasting management interest (ten percent or more of voting stock) in an enterprise operating in an economy other than that of the investor. It is the sum of equity capital, reinvestment of earnings, other long-term capital and short-term capital as shown in the balance of payments

(International Monetary Fund, Balance of Payments Statistics Yearbook).

${ }^{3}$ The eight transition countries that entered the EU in 2004 are included in this paper as transition countries, since those countries were not a member of the EU yet when the data used in this paper were collected.
} 
in 1989, whereas the FDI per capita in 1989 in the CEECs and FSU equaled only two eurocent (De Nederlandsche Bank data). Based on these data a catch up effect of the CEECs and FSU could be expected, leading to higher FDI inflows in the 1990s. Dutch FDI to the CEECs and FSU increased enormously since 1989 (see graph one). In 2002, the total FDI stock in the region was 13.600 million euro, resulting in an FDI stock per capita of 37.5 euro. This amount is almost 1900 times as high as the FDI per capita in 1989. However, the division of FDI over the countries shows large inequalities. The Czech Republic, Hungary, Poland and Russia jointly received about 90 percent of the total FDI, leaving the other 21 countries with only ten percent. This large inequality is clearly shown by the trend lines in graph one; the EU accession countries received a lot more FDI than the rest of Central and Eastern Europe and Central Asia.

\section{Graph 1: Yearly FDI inflows and stock}

Graph 1a Yearly FDI inflows

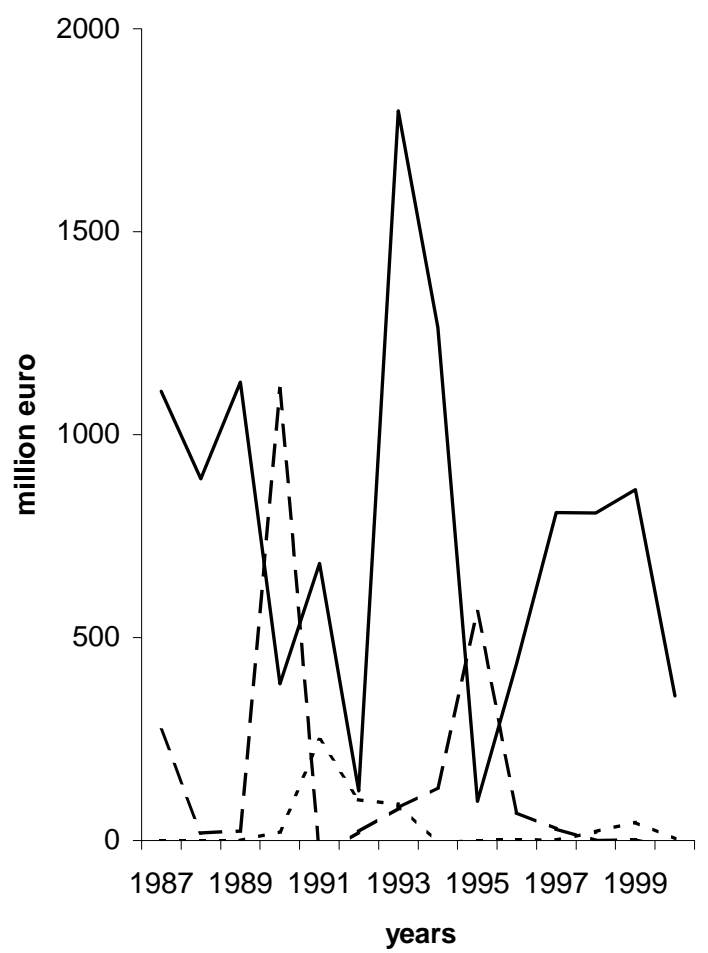

EU accession countries

- - Rest of Central and Eastern Europe

- . - . Central Asia
Graph 1b FDI stock

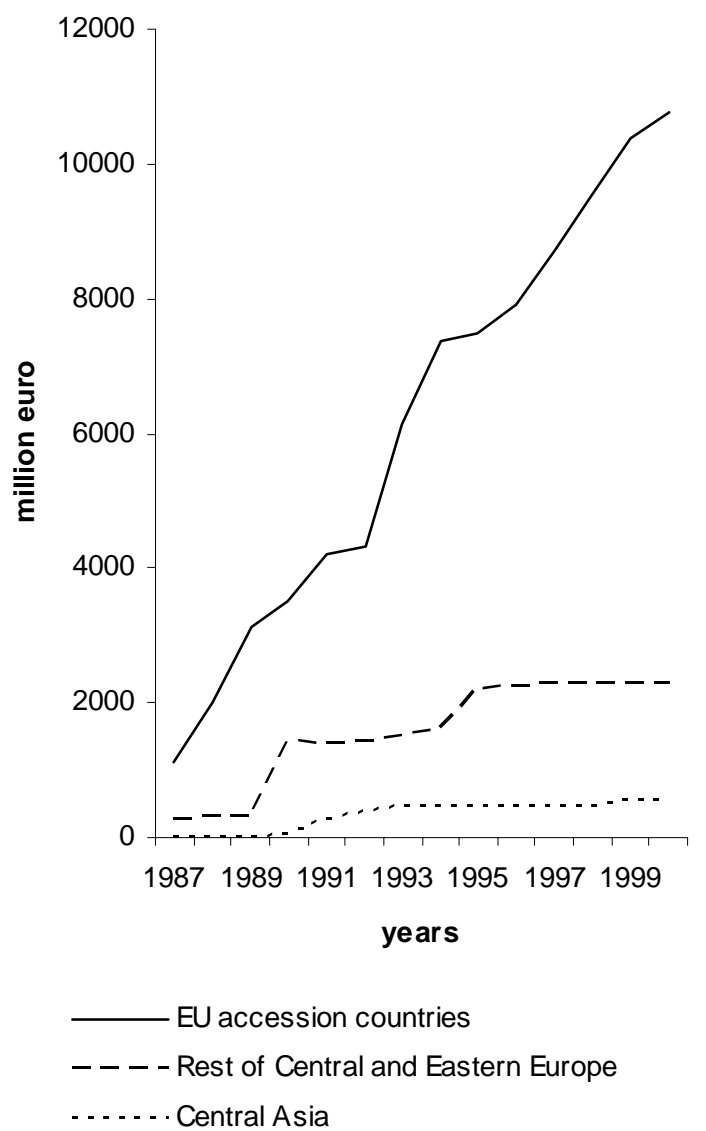

Source: De Nederlandsche Bank Balance of Payments data

Even though the increase in FDI was high in the transition countries, many firms either do not consider an investment in that region, or they do consider an investment but eventually decide not to invest. The literature, discussed in section two, suggests this could be due to the lack of financing means available to firms. These difficulties are especially present for the small and medium sized 
enterprises $\left(\mathrm{SMEs}^{4}\right)$, since those companies often have less private or company funds available to finance their investment and therefore need to rely more on external financing means. Lending locally is difficult because of an underdeveloped banking sector and local and Dutch banks are hesitant to finance those ventures because of the high risks involved in an investment and the moral hazard problem they face ${ }^{5}$. However, the results from the Dutch firm level survey data used in this paper suggest that there are possibly several other reasons that negatively influence the investment decision. The purpose of this paper is therefore to test the assumption that financial reasons are the main reason not to invest or if other reasons prevail.

In section two, literature on FDI to transition countries is summarized with specific focus on the financial obstacles those firms face when investing abroad. Section three includes a description of the database. In section four firm level data are analyzed in order to find out what holds firms from investing and to what extent these obstacles can be removed by policy measures. Section five concludes.

\section{Literature overview}

This literature overview summarizes the financing problems of SMEs investing in transition countries and not specifically the problems of foreign entrants. This is due to the fact that SMEs, being local or foreign, face most difficulties with respect to financing. However, since most Dutch enterprises entering the region are SMEs, they are likely to encounter similar problems. Larger MNEs (multinational enterprises) generally have better internal and external access to finance and the described problems will affect their entrance decision less. In the analysis in section four both SMEs and MNEs are included.

There are several reasons why financing direct investments in transition countries can be difficult. The origin of most of the financial problems lies in the fact that the transition countries do not have a long commercial banking history. During the socialist time (before 1989-1991) there was a mono banking system, with the state as owner of all banks, centrally and locally. During transition a dual banking system was installed, with a central bank and independent commercial banks. State-owned banks were privatized and foreign banks were often allowed to enter the market ${ }^{6}$ (Calvo et al, 1994).

Commercial banks faced several difficulties during their first years of operation (Blommenstein et al, 1993). They inherited a portfolio of loans that was consisting in large of bad loans, meaning loans that were provided to previously state-owned firms that were not operating according to the hard budget constraint. Banks either needed to write off those bad loans, which meant accepting a large loss, or they renewed bad loans, keeping the soft budget constraint in place (OECD, 1998; EBRD, 1999; Roland, 2000; Kornai, 2001). This last option led to crowding out, since there were no means available to provide finance to newly established firms (including foreign enterprises) as well. On top of that, commercial banks faced a moral hazard problem because the newly commercial enterprises did not have business history and accounting standards of companies were often missing or poor. This left the banks without a clear mechanisms to select the goods initiatives from the bad ones.

\footnotetext{
${ }^{4}$ SMEs are defined in this paper as firms with less than 200 employees. The literature overview in section two focuses on those SMEs, but the results of the survey described in section 4 also include larger firms.

${ }^{5}$ Not only the transition countries are risky host countries, also the FDIs themselves are a risky investment. FDIs are often newly established firms set up in a country the investor has no experience in, thus for banks it is hard to judge how solid their investment in such an FDI will be.

${ }^{6}$ Of course this process took time. Especially in the early years of transition many commercial banks were owned by the state and foreign banks were not in all countries allowed immediately after the start of transition.
} 
In addition to the bad loan problem banks had to operate in a market without clear regulations and a lack of corporate governance, specifically with respect to ownership regulations and financial rules. This lack of corporate governance led to conflicting interests of the state, often still in part owner of the banks, privatization funds and state-owned enterprises ${ }^{7}$ (OECD, 1998). The lack of regulations and bad implementation of existing regulations in many countries led to a surge of new banks, without proper rules of engagement. Banks often provided finance to firms without having the necessary reserve ratios, resulting in a large amount of loans without proper monetary backup. The quality of banks was dispersed and there was no individual bank history customers could build on when selecting their commercial bank. In several countries financial crises occurred, for instance because of bank runs (in the Baltic countries, Weller \& Morzuch, 1999) and pyramid schemes (in Albania, EBRD, 1999).

Last, there was no or little confidence in the local banking sector by the population. Individuals were hesitant to deposit their savings on local bank saving accounts, for ample reasons. The lack of a sound banking system under communism taught individuals to keep their savings in cash. This opinion was supported by the fact that the hyperinflation rates present in the early years of transition were not compensated for by high interest rates, thus in real terms the monetary value of saving accounts decreased constantly. Therefore many individuals opted for an exchange of their savings in dollars and kept their savings money at home. Consequently, banks were short of deposits (especially long term deposits) and thus unable to provide long term finance. In addition, the international country ratings of transition countries was low, making lending at the international capital market difficult as well.

Solutions suggested to deal with these financial sector problems are to install and implement clear regulations, clean the bad loan portfolios (write off bad loans) and continue to provide financial sources only to profitable firms operation according to hard budget constrains. These solutions are of course time and money consuming.

The presence of multinational banks does not necessarily increase the financial sources provided to small and medium sized enterprises in the short run. While from the host country perspective the presence of foreign banks does strengthens the banking system and improves the low level of financial intermediation, it is questionable to what extent local enterprises and SMEs benefit from their presence (de Haas et al, 2002). As Weller (2000) argues, the increase of multinational banks in Poland from zero to fifteen between 1991 and 1997 was accompanied by an overall decrease in the ratio of credit to private and public enterprises to GDP. Weller argues that the presence of multinational banks is not necessarily a merit for the local banks, since those multinational banks have a competitive advantage in terms of reputation and therefore often serve credit supply to the lower risk multinational corporations. Multinational banks generally do not offer services to SMEs, with the exception of SMEs from their home country. But even then, the service is limited to representing the bank locally and short-term finance is generally only provided to the home country SMEs if the home

\footnotetext{
${ }^{7}$ This problem was particularly present in countries that used forms of mass privatization and needed to establish privatization funds in a short period of time. For instance in the Czech Republic voucher privatization, combined with lack of corporate governance lead to a banking crisis. Situations occurred in which the government was (in part) the owner of the bank and the owner of the firm and the bank was owner of privatization funds. Banks provided soft loans to the state owned enterprises and the control mechanism in the form of monitoring privatization funds failed since they were owned indirectly by the state as well (OECD, 1998; EBRD, 1999).

${ }^{8}$ De Haas and van Lelyveld (2002) test how stable foreign financial intermediation is during financial crises and find that greenfield investments contribute to credit stability whereas takeovers reduce their credit supply during financial crises. They conclude that greenfield banking activites overall have a positive impact on stability whereas privatization of domestic banks does not lead to similar stability effects.
} 
country bank is willing to support the transaction and guarantee financial security w.r.t. the loan. ${ }^{9}$ Local banks are left to deal with the higher risk small and medium sized enterprises or start-up companies, which are not seen as profitable by banks. Domestic banks are thus left more exposed to risk and the most straightforward method of reducing their risks is reducing their loans. As a result smaller and younger firms are more likely to experience financial constraints than their older and mature counterparts and firms that face financial constraints are more likely to postpone an investment (Corricelli and Djankov, 2001; Weller, 2000; Laar, van de and Letterie, 2003). De Haas and van Lelyveld (2002) conclude in their study that foreign bank credit compared to GDP has increased in five transition countries during the years 1993-2000 and also increased in importance compared to domestic credit $^{10}$. Again, this could be an indication that although foreign credits increase they could be crowding out local banks and SMEs would have more difficulty receiving intermediary services.

Empirical studies analyzing micro data of firms investing in transition countries confirm that financing problems are high in the region ${ }^{11}$. However, almost all studies add that lack of finance is not the main or only problem. In her study to financial structures in Southeast Europe, Pissarides (2001) concludes that enterprises rely mainly on internal financing sources to finance investments. She also argues that finance alone is insufficient to support enterprise entry and a beneficial investment climate and good investment support-structure are of equal importance. This last point is one of the results of the EBRD Business Environment and Enterprise Performance Survey as well (EBRD, 1999). Survey results indicate there are four categories of barriers of entry for start-up firms, being i) (lack of) macrostabilization (inflation), ii) (lack of) legal institutional norms (corruption), iii) micro level financing constraints and iv) micro-level non-financing constraints (taxes, regulations). The key finding is that even though financing is a major problem, it is of less importance as a critical barrier for start-ups when compared to the other three mentioned barriers.

Klapper et al. (2002) study the financing of SMEs using survey data of 97.000 SMEs in the transition region. In this study it is shown that the SME sector in transition countries is still underdeveloped and the SMEs employ very few individuals. They conclude that financial constraints could impede growth of the SMEs in the region, though also larger firms in the region do not attain high growth rates. With respect to investment financing, SMEs are mainly borrowing short-term debt; this seems to be the only external financing type they can access.

Looking at financing constraints specifically, a number of problems become apparent. First, the need for connections within banks and other financial institutions is high in order to secure access to financial services. This is a clear disadvantage for SMEs and start-up firms compared to their larger older more established counterparts. Second, there is a lack of long-term bank loans, since the financial institutions themselves have a shortage of long-term deposits and therefore impose immensely high collateral requirements and high interest rates on the long-term lending transactions they are willing to finance. Last, the large paperwork and immense bureaucracy involved in acquiring a loan are very time consuming and therefore difficult for SMEs to deal with. These problems are largest in Southeast Europe and the CIS countries and less in Central Asia and the Central European States (EBRD, 1999; Pissarides, 2001; Klapper et al., 2002).

\footnotetext{
${ }^{9}$ Long-term finance is generally not considered.

${ }^{10}$ Domestic credits decreased as percentage of GDP since 1998 in Estonia, Hungary, Poland and the Czech Republic. Only in Slovenia the percentage of domestic credit to GDP was higher in 2000 than in 1998.

${ }^{11}$ Again, these studies focus on SMEs and not on FDI specifically. However, the problems are similar for Dutch SMEs trying to finance their investment abroad.
} 


\section{Survey data}

In 2000 a survey was held among Dutch firms that were interested to invest in the CEE region. In total 1550 firms were asked to participate in the survey. All firms either participated in a seminar or had requested information about doing business in the CEE region from the Dutch Chambers of Commerce. Of the 1550 firms in the sample, 330 firms responded by answering the questionnaire, of which 88 invested in the CEE region and 242 did not invest. The survey has a response rate of 23.4 percent $^{12}$. Eligible criteria for this research were that the firm had to be (partially) Dutch and the investment decision was made in the Netherlands. Firms that were ineligible based on those criteria are excluded from the database (7 investors and 25 noninvestors). Before questioning firms about their investment process in the questionnaire, the firms interested in the CEE region but not in an FDI were excluded (74 firms), as well as the firms that were in principle interested in an FDI but not in an FDI in the CEE region (94 firms). 130 firms remained in the dataset that seriously considered an FDI in the region.

\section{Financing problems of Dutch enterprises}

In order to see whether financial reasons are the main reason for Dutch enterprises not to invest abroad the before mentioned database is particularly suitable, since it not only includes those firms that did invest but also firms that were interested to invest but decided not to engage in an FDI. For simplicity purposes, the investment decision process is divided in 3 phases (see Figure one). Phase one, the orientation phase, contains the complete group of firms interested in an investment in the CEECs, that followed a seminar or requested promotion materials (total 330 firms). Firms enter phase two, the analysis phase, if they are eligible, selected one or more alternative host countries in the region and analyzed the possibilities of success of an investment in those countries. This group contains 81 investors and 49 noninvestors that already selected a potential host country to invest in. In phase three, the implementation phase, firms are included that decided to invest in a transition country and started implementing their investment.

In phase one, 168 firms indicated they were only interested in an FDI to a very limited extent. The majority of those firms (99 firms, 59 percent) never seriously considered an FDI in the CEECs but attended the seminars for other business purposes. These 99 firms can be divided in 25 firms that did not consider an FDI in general and 74 firms there were specifically not considering an FDI in the transition countries. The second group of firms (55 firms, 33 percent) indicated they decided to export their goods or services to the CEECs instead of engaging in a direct investment. The economic and political development of the region was also often mentioned as reason not to invest (13 and 6 respectively). Another five percent of the firms ( 8 firms) indicated that previous negative experiences with the CEECs led to their decision not to invest. Only four firms (two percent) indicated they decided not to consider an investment because there were no financial means available for an investment. ${ }^{13}$ These results indicate that in an early phase of the investment process the lack of finance is not the

\footnotetext{
${ }^{12}$ The respondents display a non-response bias in favor of larger older firms and firms with an investment in the CEE region. In order to take these non-response biases into account, the analysis of the data is done with and without correction for nonresponse bias. In the former analysis the data are taken with each observation weighted as one. For the latter analysis, a probability is calculated for each respondent that a firm with certain characteristics would answer the survey. The data are then weighted using the inverse probability of response, thus taking the non-response bias into account. The results of the weighted analysis are not distinctly different from the unweighted results, therefore only the unweighted results are described in this

${ }_{13}$ These four firms are all small firms, including one firm with less than five employees, two firms with $10-20$ employees and one firm with 20-50 employees.
} 
main reason to decide not to invest. More often the initial market study of a firm shows that either the CEE market is not the best region for investment or that an FDI is not the most suitable marketservicing instrument for that region. ${ }^{14}$

The firms that enter phase two are firms that all consider one or several transition countries as an interesting host countries and consider an FDI as the best market servicing mode for this region. This group of firms includes 81 investors and 49 non-investors. Only those 81 firms that decide to invest enter phase three, the implementation phase (see figure one). Table one includes summary statistics of the company groups "not interested", "noninvestors" and "investors". Contrary to the literature predictions, "investors" are significantly younger than the "noninvestors" and "not interested firms" at a five percent leve ${ }^{15}$. In line with the general findings investors are slightly larger than the firms that decided not to invest at a ten percent level ${ }^{16}$. With respect to sector division no significant differences are found. Concluding, investors are significantly younger and larger than noninterested and noninvesting forms, but it remains questionable if those company characteristics explain the choice of firms to invest or not given these results are not in line with the general findings in the literature ${ }^{17}$.

Thus, it is interesting to see whether the decision to invest can be explained by the choices made in the analysis phase. 130 firms entered phase two. They selected one or several alternative host countries in which they considered to invest and answered questions related to the kind of FDI and the method of financing they intended to use. In table two the results of those questions are included. Dutch investors highly value full ownership; given the fact that 55 percent of the investments was either a newly established firm (Greenfield) or a takeover (Brownfield). The firms that decided not to invest were more in favor of joint ventures. Possibly this is a crucial factor in their decision not to invest, since the decision not only depends on their own perspective but also on the perspective of their partner in the joint venture.

With respect to financing the data indicate there is, as the literature in section two described, a serious problem with financing through intermediaries. A majority of the firms use own money - either private or firm money - to finance their investment, whereas only 10-20 percent of the firms intend to finance their FDI by bank loans. This is easily understood when taking the high collateral rules both in the host country but also in the Netherlands into account (Klapper et al., 2002). Banks in the host country are not often considered an alternative for financing the investment. Again, this is probably predominantly due to the fact that the rules and regulations with respect to providing loans are not beneficial for the entrepreneur. On the other hand, the informal sector is never mentioned as financial source, even though this is a common financing method in the transition region (Pissarides, 2000). Subsidies, gifts and insurances are relatively more considered by noninvestors than by investors. This could for instance be due to the fact that applying for subsidies is time consuming and time and capacity are generally scarce resources in SMEs. Another explanation could be that even though there are several forms of subsidies or support available, SMEs are unfamiliar with their existence or are (or consider themselves) ineligible for participation in those programs.

\footnotetext{
${ }^{14}$ The percentages do not add to 100 percent, since each firm was allowed to select multiple answer options in the questionnaire why not to invest.

${ }^{15} \mathrm{~T}$-test results show a t-value of $\mathrm{t}=1.8689$ with $\mathrm{p}>\mathrm{t}=1.03$. Investors are also significantly younger that the non-interested group separately $(t=1.986, p>t=0.02)$, but insignificantly younger than the noninvestors $(t=0.8383, p>t=0.20)$. All tests are done assuming unequal variances.

${ }^{16}$ Investors have on average 329 employees in 1989, noninvestors and noninterested firms have on average 187 employees Seven outliers with more than 10.000 employees are excluded. three investors and four noninvestors. T-test results show a tvalue of -1.4414 with $\mathrm{p}<\mathrm{t}=0.0760$. If the outliers remain included, investors are also significantly larger at a ten percent level.

${ }^{17}$ See for instance Horst (1972), Grubaugh (1987), Agarwal and Ramaswami (1992) and Meyer (1998).
} 


\section{Figure 1: Investment decision phases}

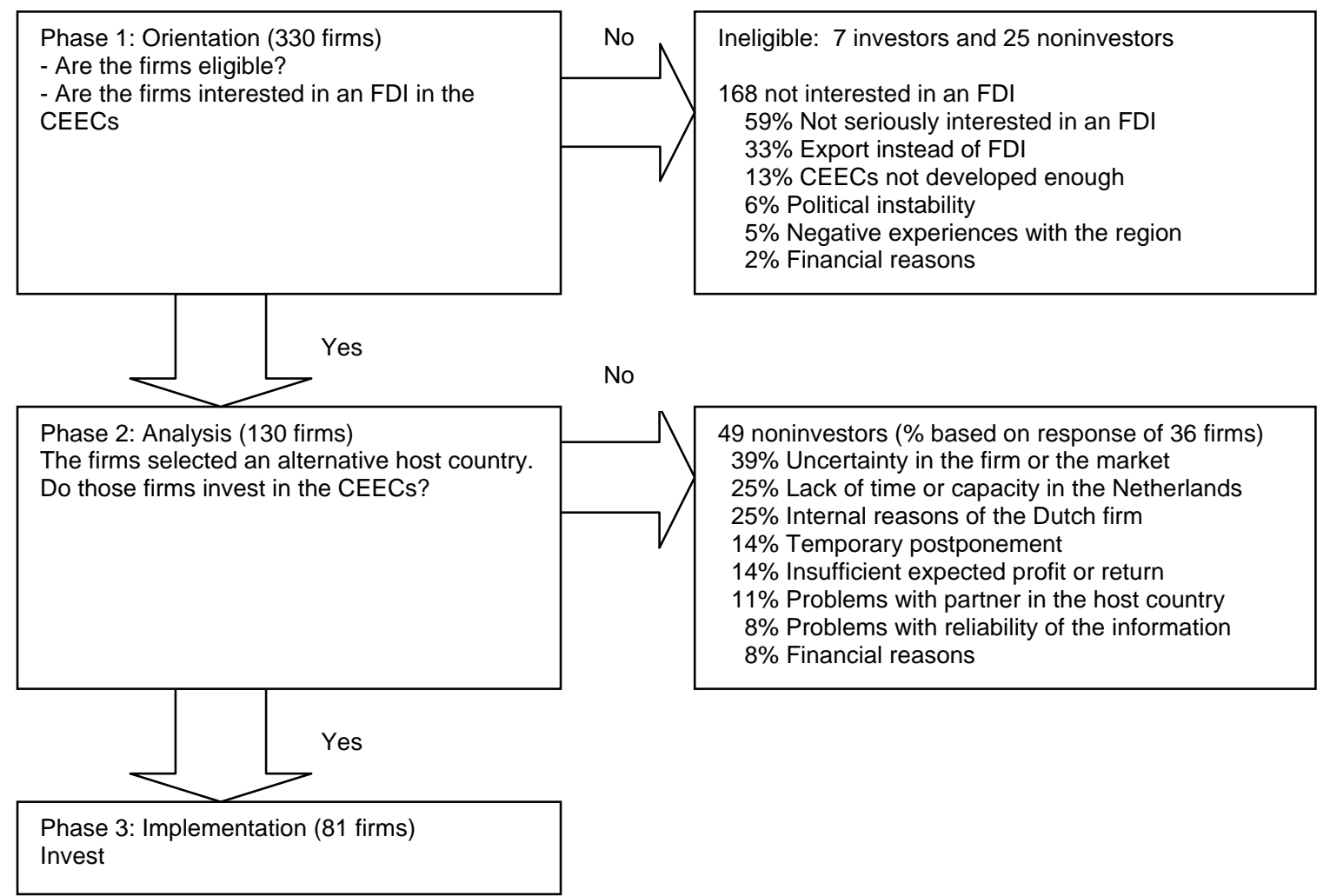

Source: Questionnaire Dutch direct investments in Central and Eastern Europe and Central Asia, Maastricht University, 2000

Table 1: Summary statistics of firms not interested in an FDI, noninvestors and investors in the CEECs

\begin{tabular}{|c|c|c|c|}
\hline & $\begin{array}{l}\text { Firms not interested in an } \\
\text { FDI in the CEECs } \\
(n=168)\end{array}$ & $\begin{array}{l}\text { Noninvestors } \\
\text { Firms interested in an FDI in } \\
\text { the CEECs that decided not } \\
\text { to invest }(n=49)\end{array}$ & $\begin{array}{l}\text { Investors } \\
\text { Firms interested in an FDI in } \\
\text { the CEECs that decided to } \\
\text { invest }(n=81)\end{array}$ \\
\hline $\begin{array}{l}\text { Sector division } \\
\text { - Agriculture } \\
\text { - Industry } \\
\text { - Construction } \\
\text { - Logistics } \\
\text { - Financial Services } \\
\text { - Retail } \\
\text { - Other }\end{array}$ & $\begin{array}{l}\text { Nr. of firms (\% division) } \\
17(10 \%) \\
88(52 \%) \\
16(10 \%) \\
9(5 \%) \\
1(1 \%) \\
29(17 \%) \\
8(5 \%)\end{array}$ & $\begin{array}{l}\text { Nr. of firms (\% division) } \\
8(16 \%) \\
22(45 \%) \\
3(6 \%) \\
1(2 \%) \\
2(4 \%) \\
10(20 \%) \\
3(6 \%)\end{array}$ & $\begin{array}{l}\text { Nr. of firms (\% division) } \\
10(12 \%) \\
29(36 \%) \\
4(5 \%) \\
12(15 \%) \\
3(4 \%) \\
15(19 \%) \\
8(10 \%)\end{array}$ \\
\hline Average age & 42.5 & 39.3 & 34.5 \\
\hline $\begin{array}{l}\text { Number of employees } \\
<5 \\
5-10 \\
11-20 \\
21-50 \\
51-100 \\
101-200 \\
201-500 \\
>500\end{array}$ & $\begin{array}{l}\text { Nr. of firms (\% division) } \\
31(18 \%) \\
14(8 \%) \\
21(13 \%) \\
31(18 \%) \\
21(13 \%) \\
19(11 \%) \\
17(10 \%) \\
14(8 \%)\end{array}$ & $\begin{array}{l}\text { Nr. of firms (\% division) } \\
14(29 \%) \\
4(8 \%) \\
7(14 \%) \\
6(12 \%) \\
4(8 \%) \\
5(10 \%) \\
5(10 \%) \\
3(6 \%)\end{array}$ & $\begin{array}{l}\text { Nr. of firms (\% division) } \\
17(21 \%) \\
5(6 \%) \\
9(11 \%) \\
9(11 \%) \\
9(11 \%) \\
7(9 \%) \\
8(10 \%) \\
16(20 \%)\end{array}$ \\
\hline
\end{tabular}

Source: Questionnaire Dutch direct investments in Central and Eastern Europe and Central Asia, Maastricht University, 2000

\footnotetext{
${ }^{18}$ The group "other" includes firms from the sectors "water, gas and electricity", "hotels and restaurants", "government services", "health" and "environment, culture and recreation". Percentages that add up to more than 100 percent are due to rounding off.

${ }^{19}$ Measured in number of employees in 1999.
} 
Table 2: Information on the (intended) kind of FDI and method of finance

\begin{tabular}{|l|l|l|}
\hline & Investors (n=81) & Noninvestors (n=49) \\
\hline (Intended) kind of FDI & Nr. of firms (\% division) & Nr. of firms (\% division) \\
- Greenfield & $10(12 \%)$ & $12(24 \%)$ \\
- Brownfield & $35(43 \%)$ & $4(8 \%)$ \\
- Joint venture & $27(33 \%)$ & $26(53 \%)$ \\
- Privatization process & $1(1 \%)$ & $3(6 \%)$ \\
- Other & $8(10 \%)$ & $4(8 \%)$ \\
\hline (Intended) method of financing & Nr. of firms (\%) & Nr. of firms (\%) \\
- Private capital of the owner & $16(20 \%)$ & $9(18 \%)$ \\
- Private capital of the Dutch firm & $61(75 \%)$ & $30(61 \%)$ \\
- Loan from financial sector in the Netherlands & $9(11 \%)$ & $12(24 \%)$ \\
- Loan from the financial sector in the host country & $1(1 \%)$ & \\
- Private capital or loan from partner in the host country & $5(6 \%)$ & $5(10 \%)$ \\
- Loan from family or friends & $0(0 \%)$ & $6(12 \%)$ \\
- Gifts, subsidies, insurances & $6(7 \%)$ & $0(0 \%)$ \\
& & $10(20 \%)$ \\
\hline
\end{tabular}

* The firms could select multiple answer options, thus percentages do not have to 100 percent.

Source: Questionnaire Dutch direct investments in Central and Eastern Europe and Central Asia, Maastricht University, 2000

Studying the method of finance by size of the firm learns that small firms most often use their own capital as main financial source, whereas larger firms rely more on intermediaries. Noninvestors planned to use bank loans more often as source of finance than investors, indicating that a failure to obtain such loans could be a reason not to invest.

A study on the relation between the extensiveness of the investment analysis undertaken by the investors and noninvestors in phase two and their final decision does not show any significant results. There is no evidence for the idea that noninvestors analyze the investment possibility less thorough and remain less informed and therefore decide not to invest. Vice versa, the idea that noninvestors are initially already less interested than investors and therefore undertake a less thorough investment analysis before deciding not to invest is incorrect as well. The survey data indicate that, once firms enter phase two of the investment decision, their analysis is of similar size irrespective of the outcome of the analysis (van de Laar, 2004 forthcoming).

The influence of the kind of (envisaged) FDI and the (envisaged) financing method on the investment decision is larger (see table three). Using a logit analysis I test whether among other variables the financing method influences the decision to invest, with investment as dependent variable. The results in table three indicate that of the firms in phase two, the firms that intend to invest by takeover are significantly more likely to invest than firms that wanted to set up a completely new company or invest in a joint venture. In addition, financing the investment using own means increases the chance a firm invests significantly, whereas financing the investment through financial intermediaries or financial means brought in by the partner firm does not influence the chance to invest. These results indicate that financing an FDI externally is a serious problem and firms that circumvent these problems by using their own means are more likely to invest. 
Table 3: Logit analysis to the determinants of FDIs

\begin{tabular}{|c|c|}
\hline Variable & Coefficient (standard error) \\
\hline Age & $\begin{array}{l}-0.005 \\
(0.008)\end{array}$ \\
\hline Size & $\begin{array}{l}0.000 \\
(0.000)\end{array}$ \\
\hline Year & $\begin{array}{l}-0.271^{* * *} \\
(0.081)\end{array}$ \\
\hline Takeover & $\begin{array}{l}1.934^{\star \star \star} \\
(0.689)\end{array}$ \\
\hline Joint Venture & $\begin{array}{l}-0.275 \\
(0.515)\end{array}$ \\
\hline Finance using private or company means & $\begin{array}{l}1.4290^{\star \star} \\
(0.681)\end{array}$ \\
\hline Finance using the financial sector in the Netherlands & $\begin{array}{l}-0.413 \\
(0.623)\end{array}$ \\
\hline Finance using the financial sector in the host country & $\begin{array}{l}-1.939 \\
(1.472)\end{array}$ \\
\hline Finance using sources from the partner firm & $\begin{array}{l}-0.530 \\
(0.815)\end{array}$ \\
\hline Constant & $\begin{array}{l}1.468^{\star} \\
(0.851)\end{array}$ \\
\hline Pseudo R2 & $0.267^{\star \star \star}$ \\
\hline \multicolumn{2}{|c|}{$\begin{array}{l}\text { Number of observations } n=129 \\
{ }^{*} \text { significant at } 10 \% \text { level, } * * \text { significant at } 5 \% \text { level, }{ }^{* *} \text { significant at } 1 \% \text { level } \\
\text { Investing in a Greenfield FDI is taken as baseline. } \\
\text { Size was measured in number of employees in } 1989 \\
\text { Year is the year the FDI was considered, measured in years that elapsed after the start of transition, so } 1989=1,1990=2 \text { etc. }\end{array}$} \\
\hline
\end{tabular}

However, this does not mean that lack of finance is the ultimate reason for firms not to invest. In order to get a better idea what the major reasons were for firms not to invest, firms were asked to answer three reasons in open format. Since firms did not have to choose from already given answer options, the most correct description of reasons why they did not invest is provided. After categorizing the mentioned reasons it became clear that, even though the previous results show finance is a problem, the major reasons not to invest were not of a financial nature. The reason most often mentioned was the uncertainty attached to the investment (in the form of for example uncertain payment structures, uncertain privatization process or uncertain regulations and a huge bureaucracy). 25 percent of the firms also mentioned a lack of time and capacity of Dutch firms as well as internal reasons (such as a too low profit of the Dutch firm or the choice to focus on the home market) (see figure one). Concrete financing problems were only mentioned by three firms (eight percent). These results are in line with the results from the EBRD survey, confirming that like SMEs. also for Dutch firms investing in an FDI macro-economic instability, and micro-level non-financing constraints (uncertainty within the firm, internal reasons) are more important than financial obstacles.

\section{Conclusion}

In literature on SMEs in transition countries it is often mentioned that the lack of a well developed financial sector in transition countries is a major reason for firms not to invest there. In addition, several studies indicate that other problems, like the uncertainty in the countries with respect to macroeconomic developments or political stability, or the lack of a legal infrastructure are of equal or even bigger importance for firms. Also foreign firms investing in a transition country face those problems. In this study Dutch survey data are used to check if financial obstacles are an important argument for Dutch firms not to engage in an FDI or if other nonfinancial arguments prevail in the decision not to invest.

The analysis shows that financial problems are indeed large, given that most of the FDI undertaken 
is financed with own means instead of using the services of financial intermediaries such as Dutch banks or banks in the host countries. Reasons for not using intermediary services are that financial intermediaries often require high collateral or ask high interest rates to secure the loans. Subsidies, gifts and insurances are not often used by the firms. Whether this is due to the fact that the available sources of subsidies are unknown or SMEs do not have the time and resources available to start a procedure remains unclear. Firms that intend to invest by takeover are significantly more likely to invest than firms that want to set up a completely new company or a joint venture. In addition, firms that (want to) finance their FDI with own means are more likely to invest, indicating that if a firm does not have the necessary financial means available to finance the FDI, the chance that it will be able to invest using other financial means is smaller.

However, the major arguments for firms not to invest are not financial in nature. The uncertainty of the investment, lack of time and capacity and internal arguments are most often mentioned as obstacles for an FDI. Financial reasons were given as well, but less often. This study therewith supports this argument offered by the mentioned empirical work undertaken in this field. Not only financial services to companies interested in an FDI in a transition country should be improved but institutional development and capacity assistance within companies during the investment decision procedure are of equal importance for a positive investment decision. 


\section{Bibliography}

- Agarwal, Sanjeev and Sridhar Ramaswami (1992), "The choice of foreign market entry mode: impact of ownership, location and internalisation factors", Journal of International Business Studies, 2, 1-27.

- Blanchard, O. (1997), "The economics of Post communist transition", Clarendon Press (Oxford).

- Blommenstein, H.J. and M.G. Spencer (1993), "The role of financial institutions in the transition to a market economy", IMF working paper, WP/93/75

- Calvo, Guillermo a. and Manmohan S. Kumar (1994), "Financial Markets and Intermediation", IMF Occasional paper Financial Sector Reform and Exchange Arrangements in Eastern Europe, 102 (1), 3-33

- Coricelli, F. and S. Djankov, (2001), "Hardening budget and enterprise restructuring: theory and an application to Romania", CEPR Discussion Paper, 2950, London

- Ebbersbach, A.. (1987), "The Development of Socialist Foreign Trade Theory in the Conditions of the 1980s", Soviet and Eastern European Foreign Trade, 23 (2), 94-117.

- EBRD, (1999), "Ten years of transition", Transition report 1999, London.

- Grubaugh, Stephen G. (1987), "Determinants of Foreign Investment", The review of Economics and Statistics, 149-152.

- Haas, de R., and I. van Lelyveld (2002), Foreign Banks and Credit Stability in Central and Eastern Europe; a panel data analysis", DNB Staff Reports, 109/2003

- Haas, de R., and I. van Lelyveld (2002), Foreign Bank Penetration and Private Sector Credit in Central and Eastern Europe", DNB Staff Reports, 91/2002

- Hermes, N. and R. Lensink, (2000), "Financial system development in transition economies", Journal of Banking and Finance, 24, 507-524.

- Horst, Thomas (1972), "Firm and Industry Determinants of the Decisions to Invest Abroad: an Empirical Study", The review of Economics and Statistics, 258-266.

- IMF, Balance of Payments Statistical Yearbook, Washington, USA.

- Kornai, J., (2001), Hardening the budget constraint: the experience of the post-socialist countries", European Economic Review, 45 (9), 1573-1599.

- Klapper, L., V. Sarria-Allende and V. Sulla,(2002), "Small and Medium size enterprise financing in eastern Europe", World Bank Policy research working paper, 2933

- Laar, van de M. (2004 forthcoming), "Dutch direct investments in Central and Eastern Europe and Central Asia", Maastricht University dissertation

- Laar, van de M. and W. Letterie, (2004), "The delaying effect of financing constraints on investment", Bulletin of Economic Research 56(3).

- Lankes, Hans-Peter and A. J. Venables (1996), "Foreign direct investment in economic transition: the changing pattern of investments", Economics of Transition, 4 (2), 331-347.

- Meyer, Klaus (1998), "Direct Investment in Economies in Transition", Edward Elgar Publishing, Cheltenham, UK, 1st edition.

- OECD (1998), "The Czech Republic", OECD Economic Surveys 1997-1999, Paris.

- Pissarides, F., (2001), "Financial structures to promote private sector development in southeastern Europe", EBRD working paper, 64.

- Raiser, M., C. Haerpfer, T. Nowotny and C. Wallace, (2001), "Social capital in transition; a first look at the evidence", EBRD working paper, 61.

- Roland, G., (2000), Transition and economics, Cambridge (Mass) \& London, MIT Press.

- Weller, C.E., (2000), "Financial Liberalization, Multinational Banks and Credit Supply: the case of Poland", International Review of Applied Economics, 14 (2), 193-211.

- Weller, C. and B. Morzuch, (1999), "Why are Eastern Europe's banks not failing", ZEI working paper, B-18.

- World Bank, (2002), Transition; the first ten years, Washington, USA. 